\title{
Profil Darah pada Sapi Simmental-Peranakan Ongole Akibat Infestasi Cacing Trematoda di Desa Labuhan Ratu, Kecamatan Labuhan Ratu, Kabupaten Lampung Timur, Provinsi Lampung
}

\section{(Blood Profiles on Simmental-Ongole Crossbreed Cattle Due to Tremathodic Infestationat Labuhan Ratu Village,Labuhan Ratu Sub-District, Lampung Timur District, Lampung Province)}

\author{
Hartono $\mathrm{M}^{1}$, Elisa ${ }^{2}$, Siswanto ${ }^{1}$, Suharyati $\mathrm{S}^{1}$, Santosa $\mathrm{PE}^{1}$, Sirat $\mathrm{MMP}^{1}$ \\ ${ }^{1}$ Dosen Jurusan Peternakan Fakultas Pertanian Universitas Lampung \\ ${ }^{2}$ Mahasiswa Jurusan Peternakan Fakultas Pertanian Universitas Lampung \\ Jl. Soemantri Brojonegoro No. 1, GedongMeneng, Rajabasa, Bandar Lampung \\ madihartono66@yahoo.co.id
}

\begin{abstract}
The aim of this study was to determine the effect of infestation of trematode worms on the number of erythrocytes, leukocytes, differential leukocyte, hemoglobin and hematocrit of Simmental-Peranakan Ongole (SimPo) cattle in December 2017 to January 2018 in Labuhan Ratu village, Labuhan Ratu sub-district, Lampung Timur district, Lampung Province. The research method was 1) collecting faecal samples from 43 SimPo cattle then identifying trematode worm eggs with sedimentation and Parfitt and Banks methods with modifications, 2) collecting blood samples from 12 SimPo cattle, 3) fecal sample examination and blood samples were carried out at the Parasitology and Pathology laboratories of Lampung Veterinary Center. The study was a completely randomized design (CRD) with three treatments and four replications, namely SimPo cattle not infested by trematode worms (P0); SimPo cattle infested with 1 type of trematode worm (Paramphistomum sp.) (P1); and SimPo cattle infested 2 types of trematode worms (Paramphistomum sp. and Fasciola sp.) (P2). The conclusions of this study shows that the total value of erythrocytes which is significantly lower total erythrocyte values are thought to be caused by the high number of infestations of the Paramphistomum sp. with the ability to perforate into the intestinal mucosa causing bleeding shown by a decrease in the total erythrocytes in the blood circulation; the differential value of leukocytes in monocytes and eosinophils higher in the blood circulation than the normal range was thought to be due to the number of infestations of the worm Paramphistomum sp. which is more than other treatments; and SimPo cattle genetically tend to be more resistant to environmental conditions and infestation of trematode worms so that the infestation of Trematode worms only affects significantly the total erythrocytes and not on other blood profile parameters (hemoglobin level, hematocrit value, total leukocytes and differential leukocytes)
\end{abstract}

Key words: Infestation, blood profile, trematode, SimPo cattle

\begin{abstract}
ABSTRAK
Penelitian ini bertujuan mengetahui pengaruh infestasi cacing trematoda terhadap profil darah (total eritrosit, total leukosit, diferensial leukosit, kadar hemoglobin dan nilai hematokrit) sapi Simmental-Peranakan Ongole (SimPo) pada Desember 2017 hingga Januari 2018 di Desa Labuhan Ratu, Kecamatan Labuhan Ratu, Kabupaten Lampung Timur, Provinsi Lampung. Metode penelitian yaitu 1) melakukan koleksi sampel feses dari 43 ekor sapi SimPo kemudian identifikasi telur cacing Trematoda dengan metode sedimentasi dan metode
\end{abstract}


Parfitt and Banks dengan modifikasi, 2) melakukan koleksi sampel darah pada sapi SimPo yang teridentifikasi terinfestasi cacing trematoda, 3) pemeriksaan sampel feses dan sampel darah dilakukan di Laboratorium Parasitologi dan Patologi Balai Veteriner Lampung menggunakan mesin automatic hematology analyser untuk penghitungan total eritrosit, total leukosit, kadar hemoglobin dan nilai hematokrit serta penghitungan manual diferensial leukosit. Rancangan penelitian berupa Rancangan Acak Lengkap (RAL) dengan tiga perlakuan dan empat ulangan yaitu sapi SimPo tidak terinfestasi cacing trematoda (P0); Sapi SimPo terinfestasi 1 jenis cacing trematoda (Paramphistomum sp.) (P1); dan sapi SimPo terinfestasi 2 jenis cacing trematoda (Paramphistomum sp dan Fasciola sp.) (P2). Kesimpulan penelitian ini menunjukkan bahwa nilai total eritrosit yang lebih rendah secara siginifikan diduga disebabkan oleh tingginya jumlah infestasi cacing Paramphistomum sp. dengan kemampuan perforasi ke mukosa intestinal sehingga menyebabkan perdarahan ditunjukkan dengan penurunan total eritrosit dalam sirkulasi darah; Nilai diferensial leukosit pada monosit dan eosinofil yang lebih tinggi dalam sirkulasi darah dari kisaran normal diduga dikarenakan jumlah infestasi cacing Paramphistomum sp. yang lebih banyak dibandingkan perlakuan lainnya; dan sapi SimPo secara genetik cenderung lebih tahan terhadap kondisi lingkungan dan infestasi cacing trematoda sehingga infestasi cacing trematoda hanya memengaruhi secara signifikan pada total eritrosit dan tidak pada parameter profil darah lainnya (kadar hemoglobin, nilai hematokrit, total leukosit dan diferensial leukosit).

Kata kunci: Infestasi, profil darah, sapi SimPo, trematoda

\section{PENDAHULUAN}

Provinsi Lampung merupakan salah satu provinsi yang menjadi lumbung ternak nasional dengan komoditi unggulan berupa sapi potong. Peternakan sapi yang ada di daerah Lampung salah satunya berada di desa Labuhan Ratu, Kecamatan Labuhan Ratu, Kabupaten Lampung Timur, didominasi oleh peternakan rakyat berskala kecil dengan populasi jenis ternak terbanyak adalah sapi Simmental Peranakan Ongole (SimPo). Program kawin silang pada sapi potong dilakukan oleh pemerintah dan peternak dalam rangka mengantisipasi tingginya kebutuhan konsumsi daging sapi dengan cara melakukan kawin silang melalui sistem perkawinan inseminasi buatan menggunakan semen sapi Simmental yang memiliki bobot lahir tinggi dengan sapi Peranakan Ongole yang memiliki kemampuan adaptasi tinggi terhadap perubahan kondisi lingkungan. Keturunan persilangan ini disebut sapi Simmental-Peranakan Ongole atau SimPo (Hardjosubroto 1994).

Trematodiasis adalah penyakit akibat infestasi cacing trematoda dalam tubuh yang dapat menyerang hati, usus, paru-paru, ginjal, dan pembuluh darah yang menimbulkan kerusakan pada tubuh ternak. Trematoda disebut cacing hisap karena memiliki alat penghisap yang terdapat di bagian anterior. Alat hisap (sucker) ini untuk menempel pada tubuh inangnya, mengisap makanan berupa jaringan atau cairan tubuh inangnya seperti darah sehingga cacing trematoda seperti Paramphistomum sp. dan Fasciola sp.) sangat merugikan. Trematodiasis pada sapi potong menyebabkan kerugian secara ekonomis karena akan menghambat pertambahan berat tubuh sapi. Gejala ini dapat dilihat melalui pengujian terhadap keberadaan parasit trematoda yang ada dalam saluran pencernaan sekaligus melihat prevalensi telur cacing melalui pemeriksaan feses sapi (Rahayu 2015). Budiono (2018) melaporkan bahwa prevalensi trematodiasis pada ruminansia besar yang ditemukan yakni 85,06\% dengan prevalensi tertinggi adalah paramphistomiasis diikuti oleh fascioliasis. Fascioliasis pada sapi dapat menyebabkan kolangitis, obstruksi saluran empedu, kerusakan jaringan hati disertai fibrosis, dan anemia, sedangkan menurut Melaku \& Addis (2012) infestasi cacing Paramphistomum sp. dalam jumlah sedikit tidak 
menimbulkan gejala klinis tetapi pada infestasi berat dapat menimbulkan gastroenteritis dan menyebabkan kematian cukup tinggi terutama pada ternak muda.

Penelitian ini bertujuan mengetahui pengaruh infestasi cacing trematoda terhadap profil darah (total eritrosit, total leukosit, diferensial leukosit, kadarhemoglobin dan nilai hematokrit) sapi Simmental-Peranakan Ongole (SimPo) di Desa Labuhan Ratu, Kecamatan Labuhan Ratu, Kabupaten Lampung Timur, Provinsi Lampung.

\section{MATERI DAN METODE}

\section{Materi}

Penelitian ini dilaksanakan pada Desember 2017 hingga Januari 2018 di desa Labuhan Ratu, Kecamatan Labuhan Ratu, Kabupaten Lampung Timur dan laboratorium Parasitologi dan Patologi, Balai Veteriner Lampung. Penelitian dilakukan dengan cara mengkoleksi sampel feses dari 43 ekor sapi SimPo untuk dilakukan identifikasi telur cacing trematoda, selanjutnya dilakukan pengambilan sampel darah pada sapi SimPo sebanyak 12 ekor sesuai perlakuan.

Rancangan penelitian ini menggunakan Rancangan Acak Lengkap (RAL) dengan tiga perlakuan yaitu:

P0 : Sapi SimPo tidak terinfestasi cacing trematoda

P1 : Sapi SimPo terinfestasi 1 jenis cacing trematoda (Paramphistomum sp.)

P2 : Sapi SimPo terinfestasi 2 jenis cacing trematoda (Paramphistomum sp dan

Fasciola sp.)

Tiap perlakuan terdiri atas 4 ekor sapi SimPo umur 3 tahun yang diambil sampel darah untuk dilakukan penghitungan total eritrosit, total dan differensial leukosit, kadar hemoglobin dan nilai hematokrit. Peralatan dan bahan yang digunakan yaitu sarung tangan, plastik feses, kotak pendingin, spuit, tabung EDTA, gelas objek, gelas penutup, beaker glass $100 \mathrm{~mL}$, methylene blue 1\%, methanol 75\%, larutan Giemsa, air, saringan 200 mesh, tabung kerucut, cawan petri/slide glass khusus, mikroskop cahaya, automatic hematology analyzer, lembar kuisioner dan alat tulis.

\section{Metode}

\section{Koleksi feses}

Prosedur koleksi feses yang dilakukan dengan mengambil feses segar secara langsung dari rektum sapi $\pm 5 \mathrm{gr} /$ sampel dan memasukkan ke dalam plastik penampung feses; memberikan label kode pada plastik penampung feses; dan memasukkan plastik penampung feses yang telah diberi kode ke dalam kotak pendingin. Feses yang telah diperoleh dikirim ke laboratorium Parasitologi Balai Veteriner Lampung dalam bentuk feses segar untuk dilakukan pemeriksaan dengan metode sedimentasi dan untuk membedakan antara cacing trematoda (Paramphistomum sp. dan Fasciola sp.) dilanjutkan dengan metode Parfitt dan Banks dengan modifikasi (Direktorat Bina Kesehatan Hewan 1999) yaitu menimbang 3 gram sampel feses lalu memasukkan ke dalam Beaker glass $100 \mathrm{~mL}$; menambahkan air hingga $50 \mathrm{~mL}$, mengaduk dengan pengaduk hingga feses hancur (homogen); menyaring suspensi dengan saringan 100 mesh dan memasukkan ke dalamtabung kerucut lalu menambahkan air hingga penuh; mendiamkan selama 5 menit, kemudian cairan bagian atas (supernatan) dibuang dan menyisakan filtrat (sedimen) $\pm 10 \mathrm{~mL}$; menambahkan air pada sedimen dalam tabung 
kerucut hingga penuh dan mendiamkan selama 5 menit kemudian membuang lagi supernatan dan menyisakan $5 \mathrm{~mL}$ sedimen; dan menuangkan sedimen ke dalam cawan petri dan menambahkan setetes Methylene Blue 1\%, selanjutnya memeriksa di bawah mikroskop dengan pembesaran 100 kali.

Identifikasi telur cacing berdasarkan morfologi dan perbedaan warna (Lihat Gambar 1) telur Fasciola sp memiliki morfologi yang hampir sama dengan telur cacing trematoda lainnya yaitu Paramphistomum sp. Telur Fasciola sp tidak menyerap warna methylene blue sehingga tetap berwarna kuning emas, terdapat operculum di salah satu kutub telur, dan gambaran sel embryonal tidak begitu jelas, sedangkan telur cacing Paramphistomum sp sebaliknya menyerap warna methylene blue sehingga berwarna kebiruan, berukuran besar, memiliki operculum dan tidak memiliki spina.

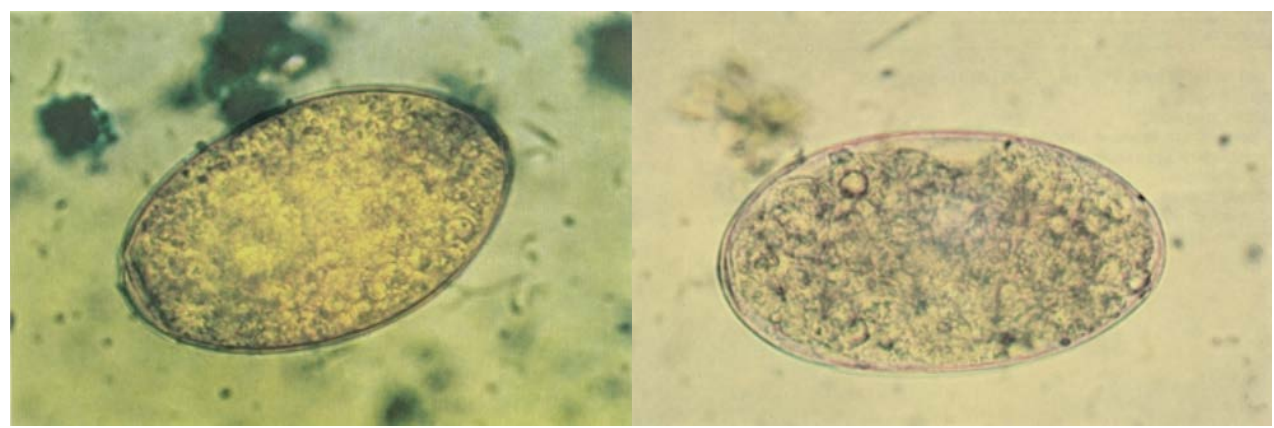

(a)

(b)

Gambar 1. Telur cacing trematoda (a) Fasciola hepatica; (b) Paramphistomum cervi

Sumber: Thienpont et al. (2003)

\section{Penghitungan total eritrosit, total leukosit, kadar hemoglobin dan nilai hematokrit}

Sampel darah diambil dari vena jugularis sapi SimPo sebanyak 5 cc menggunakan spuit volume 10 cc kemudian memasukkan darah kedalam tabung EDTA (antikoagulan) dan menyimpan dalam kotak pendingin, selanjutnya mengirim sampel darah dan pemeriksaan di laboratorium Patologi Balai Veteriner Lampung menggunakan mesin automatic hematology analyser untuk penghitungan total eritrosit, total leukosit, kadar hemoglobin dan nilai hematokrit.

\section{Penghitungan diferensial leukosit}

Berdasarkan penghitungan diferensial leukosit yang dilakukan di laboratorium Patologi Balai Veteriner Lampung, sesuai dengan prosedur pada Direktorat Bina Kesehatan Hewan (1999) dengan cara membuat preparat ulas $\pm 2 \mathrm{~cm}$ dari ujung gelas objek; memfiksasi preparat ulas dengan metanol 75\% selama 5 menit kemudian diangkat sampai kering udara; merendam ulasan darah dengan larutan giemsa selama 30 menit, diangkat dan dicuci dengan menggunakan air kran yang mengalir untuk menghilangkan zat warna yang berlebihan, kemudian dikeringkan dengan kertas isap; dan meletakkan preparat ulas dibawah mikroskop kemudian menghitung limfosit, monosit, eosinofil, basofil, heterofil secara jigjag dengan pembesaran 1000 kali sampai jumlah total 100 butir leukosit. 


\section{Analisis data}

Data yang diperoleh dianalisis dengan analisis sidik ragam satu arah (One Way Analysis of Variance/ANOVA) dan apabila diantara perlakuan menunjukkan perbedaan yang nyata $(\mathrm{P}<0,05)$ maka analisis dilanjutkan dengan Uji Beda Nyata Terkecil (BNT).

\section{HASIL DAN PEMBAHASAN}

Penelitian dilakukan dengan pengambilan sampel feses dari 43 ekor sapi SimPo kemudiansetelah dilakukan uji sedimentasi fesesmengetahui keberadaan infestasi cacing trematoda maka dilakukan pengambilan sampel darah dari 12 ekor sapi SimPo yang dibagi menjadi tiga kelompok perlakuan. Hasil yang didapatkan dari penelitian disajikan pada Tabel 1.

Tabel 1. Rataan profil darah dari tiap perlakuan infestasi cacing trematoda pada sapi SimPo

\begin{tabular}{lcccc}
\hline \hline \multirow{2}{*}{ Parameter } & \multicolumn{3}{c}{ Rataan } & Kisaran \\
\cline { 2 - 4 } & P0 & P1 & P2 & Normal* \\
\hline Total Eritrosit $\left(10^{6} / \mu \mathrm{L}\right)$ & $7,15 \pm 0,45^{\mathrm{a}}$ & $6,18 \pm 0,56^{\mathrm{b}}$ & $6,92 \pm 0,49^{\mathrm{a}}$ & $4,9-7,5$ \\
Total Leukosit $\left(10^{3} / \mu \mathrm{L}\right)$ & $10,83 \pm 4,68$ & $10,80 \pm 3,33$ & $11,43 \pm 1,69$ & $5,1-13,3$ \\
Diferensial Leukosit $\left(10^{3} / \mu \mathrm{L}\right)$ & & & & \\
$\quad$ Limfosit & $7,01 \pm 3,58$ & $6,66 \pm 2,36$ & $6,61 \pm 1,65$ & $1,8-8,1$ \\
Monosit & $1,99 \pm 1,09$ & $1,12 \pm 0,44$ & $1,81 \pm 0,47$ & $0,1-0,7$ \\
Neutrofil & $1,39 \pm 0,94$ & $1,80 \pm 0,77$ & $2,19 \pm 0,57$ & $1,7-6,0$ \\
Basofil & 0 & 0 & 0 & $0-0,2$ \\
Eosinofil & $0,44 \pm 0,25$ & $1,22 \pm 0,71$ & $0,82 \pm 0,24$ & $0,1-1,2$ \\
Kadar Hemoglobin(g/dL) & $14,38 \pm 6,78$ & $9,90 \pm 1,74$ & $11,55 \pm 1,52$ & $8,4-12,0$ \\
Nilai Hematokrit(\%) & $27,75 \pm 4,57$ & $27,00 \pm 3,46$ & $29,25 \pm 4,27$ & $21-30$ \\
\hline
\end{tabular}

Sumber: Weiss \& Wardrop (2010)

Keterangan:

P0 : Sapi SimPo tidak terinfestasi cacing trematoda

P1 : Sapi SimPo terinfestasi 1 jenis cacing trematoda (Paramphistomum sp.)

P2 : Sapi SimPo terinfestasi 2 jenis cacing trematoda (Fasciola sp. dan Paramphistomum sp.)

\section{Total eritrosit}

Total eritrosit sapi SimPo pada penelitian ini masih berada pada kisaran nilai normal menurut Weiss \& Wardrop (2010) yaitu antara 4,9-7,5 x 106/ LL.Rataan total eritrosit disajikan pada Gambar 2. Berdasarkan hasil analisis ragam menunjukkan perbedaan nyata $(\mathrm{P}<0,05)$ antar perlakuan. Setelah dilakukan uji beda nyata terkecil (BNT) bahwa terdapat perbedaan nyata antara P0 dan P1 serta P1 dan P2 yaitu kelompok perlakuan yang terinfestasi 1 jenis cacing trematoda (Paramphistomum sp.) (P1) memiliki total eritrosit lebih rendah dibandingkan kelompok perlakuan yang tidak terinfestasi cacing trematoda (P0) maupun dengan kelompok perlakuan yang terinfestasi 2 jenis cacing trematoda (Fasciola sp.dan Paramphistomum sp.) (P2). Hal ini menunjukkan bahwa infestasi 1 jenis cacing Paramphistomum sp mengakibatkan penurunan total eritrosit sapi 
SimPo di Desa Labuhan Ratu, Kecamatan Labuhan Ratu, Kabupaten Lampung Timur, Provinsi Lampung.

\section{Total leukosit}

Berdasarkan hasil analisis ragam menunjukkan bahwa infestasi cacing trematoda tidak berpengaruh nyata $(\mathrm{P}>0,05)$ terhadap total leukosit darah sapi SimPo. Rataan total leukosit disajikan pada Gambar 2.Nilai total leukosit tersebut masih dalam kisaran normal sesuai dengan Weiss \& Wardrop (2010) yaitu 5,1-13,3 $\times 10^{3} / \mu \mathrm{L}$.

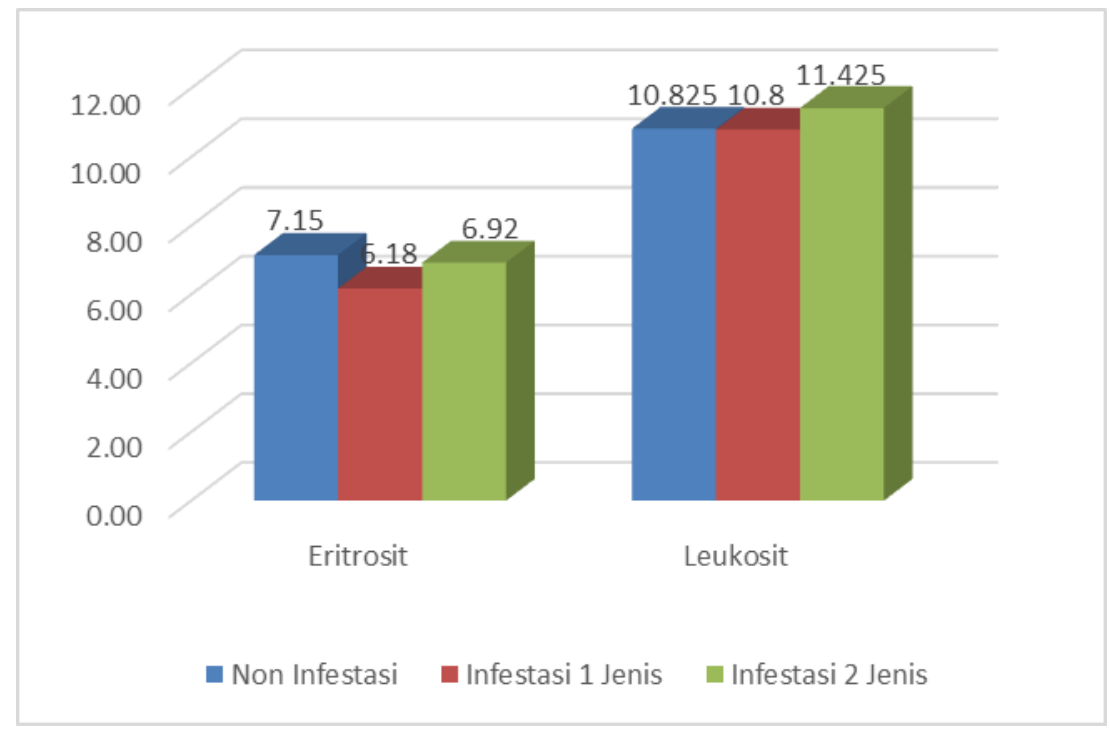

Gambar 2. Rataan total eritrosit $\left(10^{6} / \mu \mathrm{L}\right)$ dan total leukosit $\left(10^{3} / \mu \mathrm{L}\right)$ sapi SimPo pada setiap perlakuan

\section{Diferensial leukosit}

Hasil perhitungan diferensial leukosit sapi SimPo disajikan pada Gambar 3. Ratarata nilai diferensial leukosit sapi SimPo disajikan pada Tabel 1. Hasil analisis ragam menunjukkan bahwa infestasi cacing trematoda tidak berpengaruh nyata $(\mathrm{P}>0,05)$ terhadap jenis diferensial leukosit darah sapi SimPo. Nilai diferensial leukosit tersebut masih dalam kisaran normal sesuai dengan Weiss \& Wardrop (2010). 


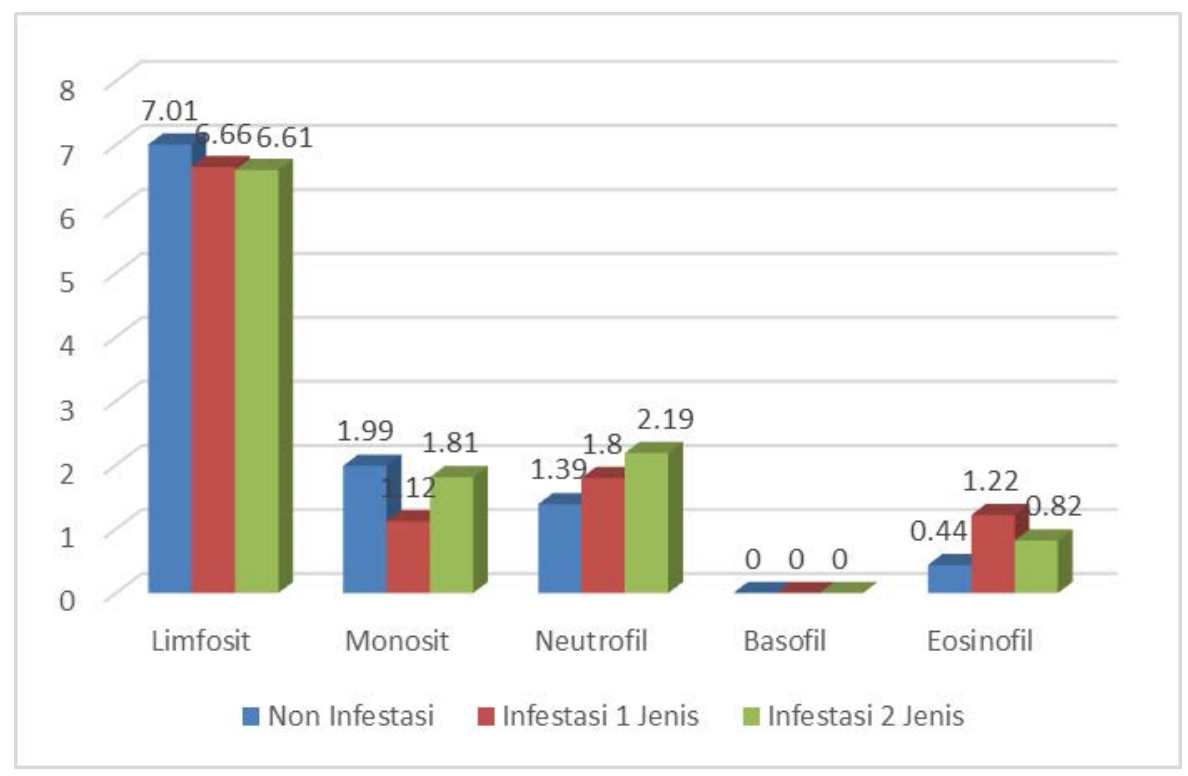

Gambar 3. Rataan diferensial leukosit $\left(10^{3} / \mu \mathrm{L}\right)$ sapi SimPo pada setiap perlakuan

\section{Kadar haemoglobin}

Hasil perhitungan kadar haemoglobin sapi SimPo disajikan pada Gambar 4. Berdasarkan hasil analisis ragam tidak terdapat perbedaan nyata $(\mathrm{P}>0,05)$ antar perlakuan. Hal ini menunjukkan bahwa infestasi cacing Fasciola sp. maupun Paramphistomum sp. tidak memengaruhi kadar hemoglobin sapi SimPo di Desa Labuhan Ratu, Kecamatan Labuhan Ratu, Kabupaten Lampung Timur, Provinsi Lampung. Kadar hemoglobin pada sapi SimPo pada penelitian ini masih berada pada kisaran nilai normal menurut Weiss \& Wardrop (2010) yaitu 8,4-12,0 g/dL.

\section{Nilai hematokrit}

Hasil perhitungan nilai hematokrit sapi SimPo disajikan pada Gambar 4. Rata-rata nilai hematokrit sapi SimPo yaitu 27,75 $\pm 4,57$ (P0); 27,00 $\pm 3,46$ (P1); dan 29,25 $\pm 4,27$ (P2) (\%). Berdasarkan hasil analisis ragam tidak ada perbedaan nyata $(\mathrm{P}>0,05)$ antar perlakuan. Hal ini menunjukkan bahwa infestasi cacing Fasciola sp. maupun Paramphistomum sp. tidak mempengaruhi nilai hematokrit sapi SimPo di Desa Labuhan Ratu, Kecamatan Labuhan Ratu, Kabupaten Lampung Timur, Provinsi Lampung.Nilai hematokrit pada sapi SimPo pada penelitian ini masih berada pada kisaran nilai normal sesuai dengan Weiss \& Wardrop (2010) yaitu 21-30\%. 


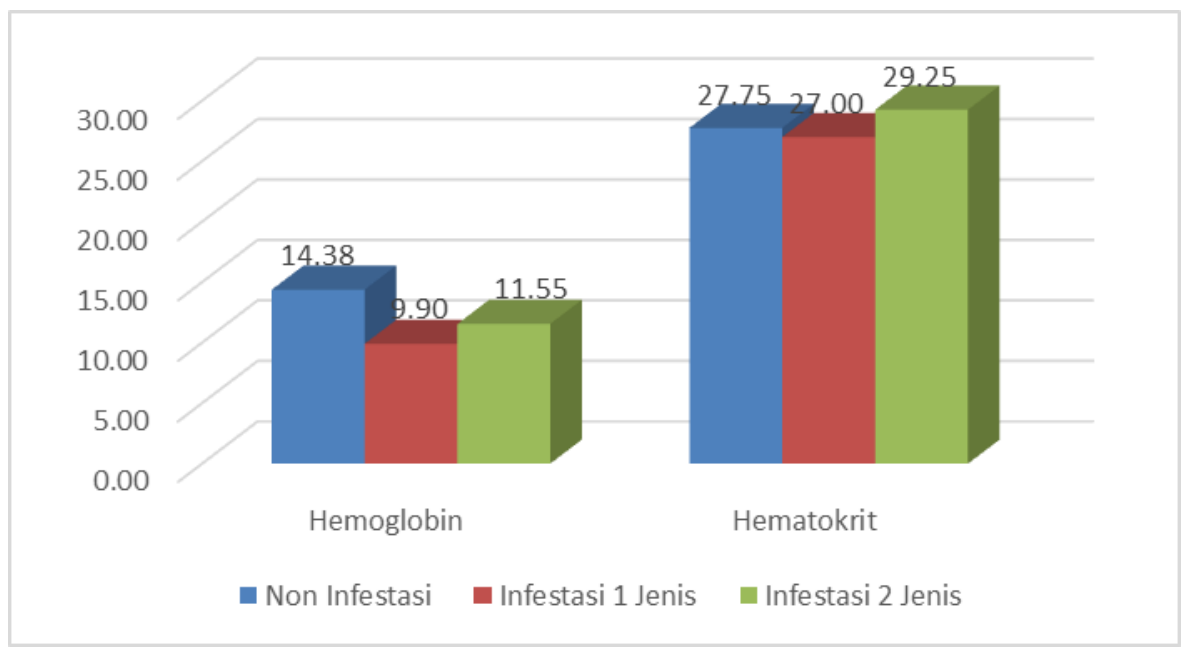

Gambar 4. Rataan kadar haemoglobin (g/dL) dan nilai hematokrit (\%) sapi SimPo pada setiap perlakuan

Penelitian ini menggunakan sampel darah 12 ekor sapi SimPo dari total 43 ekor sapi SimPo yang telah dilakukan uji sedimentasi feses untuk mengetahui keberadaan infestasi cacing trematoda. Berdasarkan keterangan Widjajanti (2004) bahwa infestasi cacing trematoda pada sapi berkaitan dengan kondisi iklim yang memungkinkan perkembangbiakan inang antaranya yaitu siput Lymnea rubiginosa. Siput tersebut lebih menyukai daerah berawa dengan air yang bergerak lambat dan aliran kecil. Area ini juga memungkinkan kelembaban yang cukup untuk kelangsungan hidup metaserkaria infektif (Phiri et al. 2006). Keberadaan siput di sekitar kandang dapat dijadikan salah satu penyebab ternak terinfestasi cacing, sebab menurut Lampage (1962) Paramphistomum sp. dan Fasciola sp. membutuhkan siput sebagai inang perantara dalam siklus hidupnya.

Infestasi cacing trematoda pada sapi SimPo di penelitian ini dimungkinkan berasal dari rumput yang dimakan atau air yang diminum oleh sapi saat digembalakan. Hal ini sesuai dengan pendapat Sugeng (2003), bahwa penularan ataupun penyebaran cacing terjadi melalui pakan atau air minum yang telah dicemari oleh larva. Infestasi cacing trematoda lewat air minum yang terkontaminasi larva stadium metaserkaria yang siap berkembangbiak. Air minum yang diberikan pada sapi SimPo berasal dari mata air yang berasal dari rawa yang kemungkinan besar terkontaminasi oleh metaserkaria yang keluar dari siput dan berenang di air mencari tanaman yang ada di pinggir perairan. Lokasi lingkungan kandang berupa kebun dengan kondisi lingkungan kandang yang kotor, dan terdapatnya genangan air memungkinkan ternak mudah terinfeksi. Lingkungan yang kotor dan adanya genangan air dapat menyebabkan siput untuk perkembangbiakan mirasidium. Menurut Noble \& Noble (1989), perkembangan dari stadium telur cacing trematoda sampai stadium metaserkaria hanya dapat terjadi pada lingkungan yang tergenang air yang bertindak sebagai faktor pembatas siklus hidup cacing di luar tubuh ternak.

Sapi SimPo memungkinkan untuk terinfestasi cacing trematoda, karena menurut Siswanto et al. (2018) prevalensi infestasi cacing trematoda (Fasciola sp.) pada sapi perah di Provinsi Lampung terutama di Kabupaten Lampung Barat diakibatkan kelompok ternak jarang dan bahkan tidak pernah melakukan tindakan pengobatan. Menurut Boray (1969) dan Direktorat Kesehatan Hewan (1980) pengobatan sebaiknya dilakukan 
sebanyak tiga kali dalam setahun, yaitu pada permulaan musim hujan untuk membasmi cacing yang diperoleh ternak selama musim kemarau, pada pertengahan musim hujan untuk membasmi cacing yang diperoleh selama musim hujan dan untuk mengurangi infestasi siput oleh mirasidium, serta pada akhir musim hujan untuk membasmi cacing yang diperoleh selama musim hujan dan mengurangi pencemaran lapangan oleh telur cacing hati di musim kemarau. Larasati et al. (2017) menyatakan bahwa penyebab tingginya prevalensi cacing saluran pencernaan karena sapi dewasa tidak pernah diberi obat cacing untuk memberantas infestasi yang lebih serius.

Parameter profil darah yang rutin digunakan untuk mengevaluasi kejadian anemia akibat infestasi cacing pada ternak adalah total eritrosit, kadar hemoglobin, dan nilai hematokrit yang memiliki hubungan berbanding lurus untuk mendeskripsikan keparahan status anemia (Weiss \& Wardrop 2010). Menurut Baldy (2003), komponen utama eritrosit adalah hemoglobin yang mengangkut sebagian besar oksigen dan sebagian kecil fraksi karbondioksida, serta mempertahankan $\mathrm{pH}$ darah normal. Sementara hematokrit merupakan persentase eritrosit dalam $100 \mathrm{~mL}$ darah yang sangat dipengaruhi oleh total eritrosit (Frandson 1992; Adam et al. 2015). Hematokrit menunjukan persentase sel darah merah tehadap volume darah total dan digunakan untuk mendeskripsikan status keparahan anemia. Penurunan nilai hematokrit merupakan indikator anemia, reaksi hemolitik, leukemia, sirosis, kehilangan banyak darah dan hipertiroid, sedangkan penurunan nilai hematokrit sebesar 30\% menunjukkan terjadinya anemia tingkat sedang hingga parah (Herawati \& Andrajati 2011). Total eritrosit, total leukosit, kadar hemoglobin dan nilai hematokrit sapi masih pada kisaran normal mengacu pada Weiss \& Wardrop (2010), walaupun total eritrosit masih pada kisaran normal, tetapi adanya infestasi 1 jenis cacing trematoda yaitu Paramphistomum sp. (P1) pada sapi SimPo memengaruhi secara signifikan penurunan total eritrosit jika dibandingkan perlakuan lainnya.Penurunan total eritrosit tersebut berbanding lurus dengan kadar hemoglobin dan nilai hematokrit, walaupun kadar hemoglobin dan nilai hematokrit masih pada kisaran normal tetapi jumlah keduanya adalah paling rendah dibandingkan perlakuan lainnya.

Menurut Sarwono et al. (2001) infeksi dari Paramphistomum sp. dapat menyebabkan reaksi peradangan, penebalan dan hemoragi mukosa usus. Cacing dewasa kurang patogen tetapi dalam jumlah besar dapat menyebabkan penebalan papilla pada rumen. Penembusan larva cacing ke dalam mukosa usus halus menimbulkan iritasi dan peradangan dinding mukosa usus halus yang disertai dengan lesi, ulser dan diare, bahkan apabila semakin parah dapat terjadi ruptur, sehingga infeksi menyebabkan menyebabkan anemia. Hal ini sejalan dengan laporan Lestari et al. (2017) bahwa fase intestinal parasit Paramphistomum sp. sangat berbahaya karena pada fase tersebut parasit melakukan perforasi masuk ke mukosa dan menyebabkan perdarahan sehingga menyebabkan penurunan total eritrosit dalam sirkulasi darah.

Sel darah putih (leukosit) berfungsi sebagai sistem kekebalan tubuh terhadap infeksi penyakit. Leukosit sebagian besar dibentuk di sumsum tulang (granulosit, monosit dan beberapa limfosit) dan sebagian kecil di jaringan limfe (sel plasma dan limfosit). Leukosit terbagi menjadi dua jenis yaitu yang tidak memiliki granula (agranulosit) seperti limfosit dan monosit dan sel granulosit (neutrophil, eosinofil dan basophil) (Hoffman \& Stock 2000). Nilai rata-rata monosit pada penelitian ini meningkat $0,1-0,7 \times 10^{3} / \mu \mathrm{L}$. Brown (1979) menyatakan bahwa monosit (makrofag) berfungsi dalam mekanisme pertahanan tubuh terhadap mikroorganisme. Peningkatan jumlah monosit di dalam darah terjadi akibat respon tubuh terhadap infeksi parasit. Menurut Hoffman \& Stock (2000) bahwa masa hidup monosit didalam sirkulasi darah hanya 10-20 jam sebelum masuk ke dalam jaringan dan menjadi makrofag dan dapat melekat di jaringan hingga berbulan-bulan 
hingga bertahun -tahun sebagai pelindung lokal spesifik. Monosit (makrofag) di dalam sirkulasi darah memiliki fungsi fagositosis bakteri, virus, parasit serta benda asing. Meningkatnya hingga dua kali lipat pada penelitian ini menandakan peradangan kronis (Fernyhough et al. 2008).

Neutrofil memenuhi 70\% jumlah sel darah putih dan sebagai fagosit yang dominan dalam sirkulasi.Neutrofil berukuran 10-12 $\mu \mathrm{m}$ dan memiliki satu inti yang berlobus 3-5 lobus dalam satu sel. Sitoplasma dipenuhi granul berwarna biru hingga merah muda tergantung dari pewarnaan yang digunakan. Nilai rata-rata neutrofil pada penelitian iniberada di bawah kisaran normal (P0), namun masih berada dalam kisaran normal neutrofil untuk P1 dan P2. Menurut Weiss \& Wardrop (2010) nilai normal neutrofil sapi yaitu $1,7-6,0 \times 10^{3} / \mu \mathrm{L}$. Neutrofil memiliki fungsi utama sebagai pertahanan pertama melawan agen infeksius, ia dapat bermigrasi hanya saat terjadinya kontak pada permukaan. Nilai neutrofil P1 dan P2 masih berada dalam kisaran normal menandakan bahwa infestasi cacing trematoda dalam tubuh sapi SimPo masih rendah sehingga ada kemungkinan bahwa tubuh belum mengidentifikasinya sebagai mikroorganisme yang membahayakan tubuh.

Eosinofil merupakan sel darah putih bergranul, apabila diwarnai dengan pewarnaan Giemsa berwarna merah muda menutupi sitoplasmanya. Ukuran eosinofil hampir sama dengan neutrofil atau lebih besar, dengan inti sama dengan neutrofil berlobus, tetapi dengan lobulasi yang tidak begitu jelas. Sitoplasmanya biru dengan granul jinggakemerahan, ukuran granul berbeda tiap spesies, pada ruminansia nampak seragam dan memenuhi sitoplasma (Reagan et al. 2013). Nilai rata-rata eosinofil normal yaitu 0,1-1,2 x $10^{3} / \mu \mathrm{L}$ (Weiss \& Wardrop 2010). Pada penelitian ini terdapat penurunan nilai rata-rata total eritrosit secara nyata pada P1 Jumlah eosinofil pada sapi SimPo yang terinfestasi 1 jenis cacing Paramphistomum sp. lebih tinggi dibandingkan jumlah eosinofil sapi SimPo yang terinfestasi 2 jenis cacing yaitu Paramphistomum sp. dan Fasciola sp. (P2), kemungkinan dapat disebabkan jumlah infestasi cacing trematoda pada P1 lebih banyak daripada P2.

Eosinofil merupakan sel fagosit yang diproduksi dalam jumlah banyak saat inang terinfeksi parasit. Menurut Frandson (1992) dan Weiss \& Wardrop (2010) peningkatan jumlah eosinofil (eosinofilia) pada ruminansia dapat disebabkan oleh infestasi parasit berupa cacing dan larva saluran pencernaan, sehingga semakin banyak infestasi cacing maka semakin tinggi eosinofil di dalam darah. Menurut Guyton \& Hall (2010), eosinofil melekat pada parasit muda dan membunuhnya, dengan cara melepaskan enzim hidrolitik dari granul-granulnya yang dimodifikasi lisosom; dapat juga dengan melepaskan bentuk oksigen reaktif yang tinggi bersifat letal terhadap parasit; melepaskan dosis tinggi polipeptida larvasidal yang disebut utama dari dasar protein. Eosinofil juga memiliki kecenderungan berkumpul di jaringan apabila terjadi reaksi alergi, seperti pada penderita asma dan reaksi alergi kulit. Hal tersebut disebabkan oleh banyaknya sel mast dan basofil melepaskan eosinophil chemotactic factor yang menyebabkan eosinofil bermigrasi ke jaringan tersebut. Eosinofil berfungsi mendetoksifikasi peradangan yang diinduksi oleh sel mast dan basofil serta memfagosit kompleks allergen-antibodi, sehingga mencegah penyebaran lebih dari proses peradangan lokal. Hariono (1993) juga menyatakan bahwa peningkatan jumlah eosinofil dalam darah kemungkinan besar karena reaksi hipersensitivitas jaringan akibat infestasi cacing.

Peningkatan eosinofil pada P1 diduga karena infestasi cacing Paramphistomum sp. dalam tubuh sapi SimPo berlangsung lebih lama (kronis) daripada infestasi 2 jenis cacing (P2). Jumlah infestasi cacing trematoda pada P1 diduga lebih tinggi daripada jumlah infestasi pada P2, namun masih tergolong infestasi rendah. Infestasi yang masih rendah 
diketahui berdasarkan kondisi fisik sapi SimPo yang belum menunjukkan gejala klinis. Javed et al. (2006) menyatakan bahwa ternak yang terinfestasi Paramphistomum sp. mengalami infeksi ringan dan tidak menunjukkan gejala klinis. Sedangkan Lestari et al. (2017) menyebutkan bahwa patologi pada rumen yang terinfestasi cacing Paramphistomum sp. sangat ringan sehingga jumlah neutrofil P1 nilainya di atas normal namun tidak memengaruhi secara signifikan dibandingkan perlakuan lainnya.

Hal yang mungkin menyebabkan total eritrosit, total leukosit, kadar hemoglobin dan nilai hematokrit sapi penelitian berada dalam kisaran normal karena sapi merupakan hasil silangan Simmental-Peranakan Ongole. Menurut Nicolas (1989), variasi genetik jenis hewan dapat mempengaruhi ketahanannya terhadap infeksi parasit, sedangkan menurut Labetuben et al. (2014) sapi SimPo banyak dipelihara karena dapat beradaptasi dengan baik, sehingga sapi-sapi pada penelitian ini cenderung lebih tahan terhadap kondisi lingkungan dan infestasi cacing trematoda. Selain itu, tidak ditemuinya siput pada lingkungan sekitar kandang menandakan bahwa tidak terjadi infestasi trematoda secara berulang. Telur cacing yang keluar bersama feses sapi dan menetas menjadi mirasidium akan mengalami kematian jika tidak menemukan inang perantara.

\section{KESIMPULAN}

Berdasarkan hasil penelitian dapat disimpulkan bahwa profil darah akibat infestasi cacing trematoda pada Sapi SimPo berupa: (1) Nilai total eritrosit yang lebih rendah secara siginifikan diduga disebabkan oleh tingginya jumlah infestasi cacing Paramphistomum sp. dengan kemampuan perforasi pada lapisan mukosa intestinal sehingga menyebabkan perdarahan yang ditandai dengan penurunan jumalah eritrosit dalam sirkulasi darah. (2) Nilai diferensial leukosit pada monosit dan eosinofil meningkat dalam sirkulasi darah diduga disebabkan oleh infestasi cacing Paramphistomum sp. yang lebih banyak dibandingkan perlakuan lainnya. (3) Sapi SimPo secara genetik cenderung lebih tahan terhadap kondisi lingkungan termasuk terhadap infestasi cacing trematoda sehingga hanya berpengaruh secara signifikan pada total eritrosit dan tidak pada parameter profil darah lainnya (kadar hemoglobin, nilai hematokrit, total leukosit dan diferensial leukosit).

\section{DAFTAR PUSTAKA}

Adam M, Lubis TM, Abdyad B, Asmilia N, Muttaqien, Fakhrurrazi. 2015. Jumlah eritrosit dan nilai hematokrit sapi Aceh dan sapi Bali di Kecamatan Leumbah Seulawah Kabupaten Aceh Besar. J Med Vet. 9:115-118.

Baldy CM. 2003. Gangguan sel darah putih dan sel plasma. Dalam: Price SA, Wilson LM, penyunting. Patofisiologi konsep klinis proses-proses penyakit. Jakarta (Indonesia): Penerbit Buku Kedokteran.

Boray JC. 1969. Experimental fascioliasis in Australia. Adv Parasitol. 7:95-210.

Brown HW. 1979. Dasar parasitologi klinis. Edisi 3. Rukmono B, Hoedojo NS, Djakaria SD, Soeprihatin SS, Oemijati MS, Gandahusada S, Pribadi W, penerjemah. Jakarta (Indonesia): PT Gramedia.

Budiono NG. 2018. Trematodiasis pada sapi dan kerbau di wilayah endemik schistosomiasis di Provinsi Sulawesi Tengah, Indonesia. J Ilmu Pertanian Indonesia. 23:112-126. 
Direktorat Bina Kesehatan Hewan. 1999. Manual standar metode diagnosa laboratorium kesehatan hewan. Jakarta (Indonesia): Direktorat Bina Kesehatan Hewan, Direktorat Jenderal Peternakan, Departemen Pertanian.

Direktorat Kesehatan Hewan. 1980. Pedoman pengendalian penyakit hewan menular Jilid II. Jakarta (Indonesia): Direktorat Kesehatan Hewan, Direktorat Jenderal Peternakan, Departemen Pertanian.

Fernyhough L, Leathart C, Theakston E. 2008. Complete blood count in primary care. Bpaz. Dunedin

Frandson RD, Wilke WL, Fails AD. 2009. Anatomy and physiology of farm animals. 7th ed. Iowa (USA): Wiley-Blackwell.

Hardjosubroto W. 1994. Aplikasi pemuliabiakan ternak di lapangan. Jakarta (Indonesia): PT Grasindo.

Hariono B. 1993. Hematologi [Internet]. [Diakses 23 April 2019]. Tersedia dari: http://www.diaglab.vet.cornell.edu/clinpath/modules/heme1/lymphocyte.htm.

Herawati F, Andrajati R, Umar F. 2011. Pedoman interpretasi data klinik. Jakarta (Indonesia): Kementerian Kesehatan Republik Indonesia.

Hoffman R, Stock W. 2000. White blood cells 1: Non-malignant disorders. Lancet. 355:13511357.

Javed KU, Akhtar T, Maqbool A, Aness A. 2006. Epidemiology of paramphistomiasis in buffaloes under different managemental conditions at four districts in Punjab Province Pakistan. Iranian J Vet Res. 7:68-73.

Labetuben J, Parera F, Saiya S. 2014. Evaluasi pelaksanaan inseminasi buatan pada sapi Bali di Kabupaten Halmahera Utara. J Agrinimal. 4:22-27.

Lampage G. 1962. Monning's veterinary helminthology and enthomology. 5th ed. London (UK): Balliete and Cox.

Larasati H, Hartono M, Siswanto. 2017. Prevalensi cacing saluran pencernaan sapi perah periode Juni--Juli 2016 pada peternakan rakyat di Provinsi Lampung. J Pen Pet Indones. 1:8-15.

Lestari AAIIJ, Adnyana IBM, Oka IBM. 2017. Prevalensi dan gambaran patologi infestasi cacing Paramphistomum spp pada rumen sapi Bali yang dipotong di rumah potong hewan (RPH) Kota Denpasar. Indones Medic Vet. 6:20-29.

Melaku S, Addis M. 2012. Prevalence and intensity of paramphistomum in ruminants slaughtered at Debre Zeit Industrial Abattoir Ethiophia. Glob Vet. 3:315-319.

Nicolas FW. 1989. Veterinary genetics. Associate Profesor, School of Animal Husbandry, University of Sydney. Oxford (UK): Clarendon Press.

Noble ER, Noble GA. 1989. Parasitologi: Biologi parasit hewan. Edisi Kelima. Wardianto, penerjemah. The parasitology: The biology of animal parasites. Yogyakarta (Indonesia): Gadjah Mada University Press.

Phiri AM, Phiri IK, Monrad J. 2006. Prevalence of paramphistomiasis and its association with Fasciola gigantica infection in Zambian cattle from communal grazing areas. J Helmint. 80:65-68.

Reagan WJ, Roveira ARI, DeNicola DB. 2013. Veterinary hematology: Atlas of common domestic an non-domestic species. 2nd ed. Philadelphia (USA): WiIley-Blackwell.

Sarwono, Arianto B, Hario B. 2001. Penggemukan sapi potong secara cepat. Depok (Indonesia): PT Penebar Swadaya. 
Siswanto, Hartono M, Santosa PE, Suharyati S, Larasati H, Sirat MMP. 2018. Prevalensi cacing hati sapi perah pada peternakan rakyat di Provinsi Lampung. J Ilmiah Peternakan Terpadu. 6:167-172.

Sugeng Y. 2003. Sapi potong. Depok (Indonesia): PT Penebar Swadaya.

Thienpont D, Rochette F, Vanparijs OFJ. 2003. Diagnosing helminthiasis through coprological examination. 3rd ed. Beerse (Belgia): Janssen Animal Health.

Weiss D, Wardrop KJ. 2010. Schalm's veterinary hematology. 6th ed. Philadelphia (USA): Wiley-Blackwell.

Widjajanti S. 2004. Fasciolosis pada manusia: Mungkinkah terjadi di Indonesia?. Wartazoa. 14:65-72. 